\title{
INTERNATIONAL COPYRIGHT IN THE UNITED STATES: A CRITICAL ANALYSIS
}

\author{
JoHN SCHULMAN*
}

"Participation in the Universal Copyright Convention by the United States will not only significantly improve the protection accorded to United States private interests abroad, but will make a substantial contribution to our general relations with other countries of the free world. Early action by the United States with respect to ratification of the convention will enable the United States to play a leading part in helping to improve international relations in this important field."

The statement quoted concludes the report of Secretary of State Dulles recommending ratification of the Universal Copyright Convention, which President Eisenhower submitted to the Senate on June 10, 1953. ${ }^{1}$ The treaty itself was completed at Geneva, Switzerland, on September 6, 1952, after five years of intensive preparatory work, and has been signed provisionally by forty nations, including the United States. 2

Although the practical necessity of improving the increasingly unsatisfactory state of internal copyright procedure has been recognized for some time, an acceptable

-A.B. I916, College of the City of New York; LL.B. 1918, Columbia University. Member of the New York bar and of the firm of Hays, St. John, Abramson, and Schulman, New York City. Member of the United States Delegation to the following Conferences on International Copyright: Brussels Conference for the Revision of the Berne Convention, 1948; Sixth Annual Conference of United Nations Educational, Scientific and Cultural Organization (UNESCO), at Paris, 1951; Conference on Copyright, Pan American Union in Washington, D. C., 1952; Geneva Conference for the Preparation of the Universal Copyright Convention, at Geneva, 1952. Member of the Committees of Experts on Copyright, convened by UNESCO at Paris, 1947, 1949; member of the Committee of Experts on Copyright, convened by UNESCO, at Washington, D. C., I950.

'The Universal Copyright Convention of 1952, Exec. M., 83d Cong., Ist Sess. 4 (1953). See 99 Cong. Rec. 6554 (June ro, 1953).

2 The text of the convention is printed as an enclosure with Executive M. Signatories at Geneva were: Andorra, Argentine Republic, Australia, Austria, Brazil, Canada, Chile, Cuba, Denmark, Finland, France, German Federal Republic, Guatemala, Haiti, Holy See, Honduras, India, Ireland, Italy, Liberia, Luxembourg, Mexico, Monaco, Nicaragua, Netherlands, Norway, Portugal, Salvador, San Marino, Spain, Sweden, Switzerland, United Kingdom of Great Britain and Northern Ireland, United States, Uruguay, Yugoslavia. Since then, Peru, Israel, Belgium and Japan have signed. See 6 UNESCO Copyright Bulletin No. I, p 2. (1953.) The signatures are provisional, subject to ratification, and the convention will come into force three months after the deposit of twelve instruments of ratification, at least four of which are states not members of the International Union for Protection of Literary and Artistic Works (Berne). Subsequently it will come into force in respect of any state three months after that state deposits its ratification (Convention, Art. IX). For discussion of the convention, see REPORT of THE CommitreE oN International Copyrights (Edwaro Sargoy, Chairman) to the Annual Meeting of the Section of Patents, Trademarks, and Copyright of the American Bar Assoctation (Boston, i953); R'eport of the Comaittee on International Copyright Relations of the Section of International and Comparative Law of the American Bar Association (Boston, x953) (these are not official statements of the Association, which has not as yet considered the treaty); Dubin, The Universal Copyright Convention (a lecture delivered at the University of California at Berkeley in November, 1953, and which is about to be published); Henn, The Quest for International Copyright Protection, 39 Connell L. Q. 43 (1953); Farmer, Universal Copyright Convention Signed, Now Awaits Ratification, I62 Publishers WeEriy 1422 (Sept. 27, 1952); Schulman, A Realistic Treaty, The American Writer (November, 1952). 
remedial formula has been found only recently. The scope of this article will be an examination of some of the difficulties which are presently encountered, the conflicts which must be resolved, and the solutions proposed by the Universal Copyright Convention.

The desire on the part of the nations of the free world to establish an adequate international agreement to safeguard rights in literary, scientific and artistic works, is motivated by considerations of the same character which led the framers of the American Constitution to delegate power to enact copyright legislation to Congress, instead of reserving that area of government to the individual states. ${ }^{3}$ The flow of ideas and the interchange of information and culture are not and cannot be limited to territorial boundaries, and any legal system designed to stimulate and sustain creative effort in literature, science, and art by safeguarding the rights of authors and other copyright owners must take that factor into account.

We in the United States are both an importing and exporting nation in this field. We read books and periodicals originating abroad, see the plays written by authors of different nationalities, listen to rhumbas and tangos composed in LatinAmerica, and avail ourselves of motion pictures made in various parts of the world. The rest of the world at the same time reads our books and magazines, enjoys our plays, dances to our music, and flocks in droves to see our motion pictures. Commerce in ideas and in intellectual property has become the commonplace among the peoples of the world, instead of being the subject of enjoyment by small and select groups. So the basic objective of international copyright to establish a legal system which will encourage and promote the dissemination of literature, information, and art among nations is no different than that which prevails in the domestic sphere. But the methods of attaining this goal may depend upon economic, cultural and political considerations somewhat different from those which apply in the enactment of purely internal legislation.

Under the early statutes of most countries copyright was available only to nationals of that country, or to works first domestically published, and as a consequence works of foreign origin received no protection and could be freely reproduced. The unauthorized, but legally permissible, reproduction of English books and published plays in the United States created hostility abroad and a great deal of embarrassment among thoughtful people in the United States. ${ }^{4}$ Practices of this kind were not confined to the United States, and a widespread resentment against the injustices of legalized literary piracy led in the nineteenth century to a demand for its elimination throughout Europe and the Americas. In the United States, international copyright was established in $189 \mathrm{x}$ by the adoption of the Chace Act, ${ }^{5}$ under which foreign authors could for the first time secure protection for their works in this country. The

${ }^{3}$ U. S. Const. Art. I, $\$ 8, \mathrm{cl}$. 8: "The Congress shall have power . . . to promote the Progress of Science and useful Arts by securing for limited Times to Authors and Inventors the exclusive Right to their respective Writings and Discoveries."

"George H. Putham, The Question of Copyright (2d ed. i896); Richard R. Bowker, Copyright, Its History and Its Law c. Ig (IgI2).

${ }^{5}$ Act of Mar. 3, I891 (26 STAT. 1106, c. 565, §13). 
European countries had acted earlier in their domestic legislation, had then experimented with bilateral treaties to obtain international safeguards for their nationals, and had finally, in $\mathrm{x} 886$, established the Berne Union which has since functioned as the outstanding agency for the advancement of international copyright. ${ }^{6}$ The American Republics made various attempts to establish multilateral treaties, commencing in I88g, and established the Buenos Aires Convention in I910.

Since the establishment of international copyright, there has not been any controversy concerning its justification and utility. However, as may well be expected, experience has demonstrated the inadequacies of many of the earlier arrangements. So in the past forty years continuous efforts have been made to modernize the systems which had been originally adopted.

The Berne Convention has been revised from time to time, ${ }^{8}$ but the United States has rejected recommendations for adherence to any of the versions of the treaty. We ratified the Buenos Aires Convention of I9Io, but when an attempt was made to replace this treaty by a new one in 1946 , the opposition was so strong that no action was taken. The United States is still operating for the most part under the statutory system of bilateral arrangements adopted in Igog and patterned after the Chace Act of r8gr.

A consideration of the present status of international copyright readily reveals the necessity for a change. Statutory copyright in the United States, which must be secured for published works and is available optionally for some unpublished material, is extended to foreign authors (other than nationals of Buenos Aires Convention countries) on a basis of "bilateral arrangements," our statute making its benefits available to the works of authors who are citizens or subjects of a country which grants the benefit of copyright to American authors. ${ }^{10}$ The existence of this

\footnotetext{
- For a general discussion of the origin and development of the Berne Convention, see STEPHEN P. Ladas, The International Protection of Literary and Artistic Property (i938); Schulman, Another View of Article III of the Universal Copyright Convention, [1953] WIs. L. REv. 299-301. The members of the International Union for the Protection of Literary and Artistic Works as of Jan. I, 195I, were as follows: Germany, Australia, Austria, Belgium, Brazil, Bulgaria, Canada, Denmark, Spain, Finland, France, Great Britain, Greece, Hungary, India, Ireland, Iceland, Israel, Italy, Japan, Lebanon, Liechtenstein, Iuxembourg, Morocco (French Zone), Monaco, Norway, New Zealand, Pakistan, Netherlands, Poland, Portugal, Roumania, Siam, Sweden, Switzerland, Syria, Czechoslovakia, Tunisia, Union of South Africa, Vatican City, Yugoslavia. Documents de lA Conference reunis A BruXeldes, de 5 AU 26 JuIn, I948 (BERNe BuREAU, r95 I). My most recent information is that the following countries have ratified or adhered to the Brussels revision: Austria, Belgium, Brazil, Spain, France and Algeria, Liechtenstein, Luxembourg, Monaco, Portugal, Union of South Africa, Vatican City, Yugoslavia, Israel, Turkey, Morocco, Tunisia, Philippines, Italy. Le Droit d'Auteur, Jan. I5, I953. Revue Internationale du Droit D'Auteur II7 (Jan. I954).

${ }^{7}$ Manuel Canyes, Paul A. Colburn, and luis Gutllermo Piazza, Copyright Protection in the americas (Pan-American Union Law and Treaty Series No. 33) ir-22 (2d ed. 1950); Schulman, supra note 6 , at 301 .

${ }^{8}$ At Berlin, 1908; Rome, 1928. For text through the Rome Convention, see Ladas, op. cit. supre note 6, at Ir23-Ix74. The Convention was last revised at Brussels in 1948 . For the Brussels text, see Howeli, The Copyright Law 3 ri -325 (3d ed. I952).

- Sce, for example, Speciar Report of the Committee on Copyrights of the American Bar Association (r946). For text of Inter American Convention, see Canyes, Colborn, and PiazzA, op. cit. supra note 7, at $207-213$.

${ }_{10}$ I7 U. S. C. $\$ 9($ b) (Supp. 1952). Stateless persons are entitled to secure copyright. Houghton Mifflin Co. v. Stackpole Sons, I04 F. 2d 306 (2d Cir. 1939), cert. denied, 308 U. S. 597 (1939).
} 
reciprocity and the availability of copyright to a foreign country's nationals must be established by Presidential Proclamation, hence the reference to "proclaimed countries" and "proclaimed nationals."11 An author who is a national of a country not proclaimed may secure statutory copyright only if he is domiciled in the United States at the time of first publication of his work. ${ }^{12}$

At first blush, this bilateral procedure seems a logical method of dealing with those countries with whose copyright system we are satisfied and of bargaining with those nations from whom we require better standards. Unfortunately, however, this theoretically attractive pattern does not work out in practice. One needs no better proof of its inadequacy than the eagerness with which our publishers and other industries seek Berne Convention protection (by indirection) wherever possible, in preference to taking the risks of relying upon our own international arrangements.

The weakness in our pattern of bilateral arrangement lies in its implicit assumption that the nexus of international copyright exists between the United States and the British Commonwealth, and that only printed matter in the form of books and periodicals written in the English language is involved. This concept originally had some justification because throughout the period between $\mathbf{1 8 3 7}$, when a Senate Committee first recommended the extension of copyright to foreign authors, and Igog when the Copyright Act was last revised, the debate on international copyright waged between those who complained of the injustice of denying copyright to the British author, and those who warned of the dangers to the American publisher and printer from competition with books originating in England. ${ }^{13}$ One finds only passing reference in the copyright literature of that era to the necessity of protecting the rights of American authors abroad, to the use in international areas of intellectual property other than books, or to the problems arising in relation to books written in languages other than English. Copyright in rgog was still geared to the printing press, and the impact of motion pictures, high fidelity recording and reproduction of sound, and radio and television broadcasting upon copyright was not yet foreseen. ${ }^{14}$

As a basis for an agreement on international copyright with the British Commonwealth, under the conditions prevailing in $x 909$, the pattern of a bilateral reciprocal arrangement represented a pragmatic solution of a pressing problem. But it is wholly inadequate for dealing with intellectual property on a global scale and could not have survived as long as it has were it not for our unilateral access to the Berne Convention and, to a lesser degree, our participation in the Buenos Aires Convention. To appreciate the implications of bilateral international dealings in contrast with

\footnotetext{
${ }^{11}$ Proclamations, Treaties and Conventions Establishing Copyright Relations Between the Uniled States of America and Other Countries, I7 U. S. C. A. p. 80 (1952).

${ }^{12}$ Leibowitz v. Columbia Graphophone Co., 298 Fed. 342 (S. D. N. Y. 1923). See Bong v. Alfred S. Cảmpbell Art. Co., 214 U. S. 236 (I909); G. Ricordi v. Columbia Graphophone Co., 258 Fcd. Z2 (S. D. N. Y. rgrg).

${ }^{23}$ See generally, PutwaM, op. cit. supra note 4 , and Bowker, op. cit. supra note 4, at 364-365.

14 Richard G. De Wolf, An Outzine of Copyright Law ix, xxii (r925).
} 
the establishment of relationships under multilateral treaties or conventions, it is essential to take into account some of the unique characteristics of copyright. Although most countries of the world have copyright systems, they stem from a variety of traditions and rest upon differing philosophies. Domestic statutes follow the local doctrine with the consequence that rights in books, plays, songs, and motion pictures may be involuntarily destroyed and irretrievably lost in some localities, because of the performance of acts establishing those very rights under other systems. National status of the author or his domicile, the place of creation or of publication of a work, and acts attendant upon the publication or other reproduction of the work in one form or another, may each have a bearing upon the right of an author to claim the benefit of copyright under the laws of various countries, and these are the factors with which international copyright systems must deal.

The broadest base of copyright protection is that afforded under the AngloAmerican doctrine of the common law right of literary property, which rests upon the philosophy that an author has a natural right of property in the work he creates. Accordingly, this non-statutory copyright, perpetual in duration and not requiring compliance with any formalities, is available to alien and citizen alike. ${ }^{\mathbf{1 5}}$ It endures, however, only as long as the work remains "unpublished," since common law protection terminates upon the reproduction and general distribution or sale of copies. In as much as the performance of a play, the public rendition of a song, the exhibition of a motion picture, or even the limited distribution of copies of any work does not constitute "publication" within the meaning of copyright law, the author's broad non-statutory exclusive right in his works is an important factor in the market which deals with literary property. ${ }^{16}$

But permitting a work to be exploited by performance or by other means in its technically "unpublished" status may lead to completely different results in countries outside the United States. In all code countries, copyright both in published and unpublished works has always been regulated entirely by statute, and in England and her Dominions the distinction between common law and statutory copyright was abolished in I9II. ${ }^{17}$ In some foreign countries, unpublished works of American origin receive no protection at all; in others, protection depends upon the securing of statutory copyright in the United States, or upon compliance with local statutory requirements. ${ }^{18}$

${ }^{10}$ Palmer v. De Witt, 47 N. Y. 532 (1872); Ferris v. Frohman, 223 U. S. 424 (1912).

${ }^{10}$ Schulman, Authors Rights, 7 Copyright Problems Analyzed r9 (Commerce Clearing House, 1952): McCarthy \& Fischer v. White, 259 Fed. 364 (S. D. N. Y. 1919); Orlando Tompkins v. Halleck, 133 Mass. 32 ( 1882 ); Ferris v. Frohman, 223 U. S. 424 (I9I2); Uproar Co. v. National Broadcasting Co., 81 F. 2d 373 (Ist Cir. 1936); but see, Shapiro, Bernstein \& Co. v. Miracle Record Co., 9x F. Supp. 473 (N. D. Ill. 1950); McDonald, The Law of Broadcasting, 7 Copyright Problems Analyzed 31, $44,46-47$ (1952).

${ }^{17}$ E. J. MacGilingay, The Copyright Act, igi I Annotated 7-II (London, 1912); Capinger and Skone James, The Law of Copyright 4, 21 (8th ed. x948); Harold G. Fox, The Canadian Law of Copyright 55 (1944).

${ }^{18}$ Compare status in Great Britain, Howell, op. cit. supra note 8, at 195-196, 298-300, Copinger AND SKone James, op. cit. supra note 77 , at 291, with that in Canada, Howell, op. cit, supra note 8, at I96-200, Fox, op. cit. stpra note 17, at 550; as to Latin American countries, see CaNXEs, ColboRN AND Piszza, op. cit. supra note 7 , at $\mathbf{1 7 2}$. 
Publication brings into play a new set of factors. In the United States, publication terminates common law copyright and limits the enjoyment of protection to the terms of the statute. ${ }^{19}$ It is at this juncture that compliance with formalities becomes necessary. Statutory copyright is available in the United States only to the limited class of foreign authors who qualify on the basis of their nationality, and for this purpose the nationality of the publisher of the work or the situs of publication is immaterial. ${ }^{20}$

In most countries outside the United States, the criterion of protection is the place of publication and even nationals of these countries lose enjoyment of copyright if their works are first published outside the area prescribed by the domestic law. ${ }^{21}$

The primary problem in international copyright is not so much the quality of protection accorded to a work after it becomes entitled to the benefit of copyright, but how to acquire the right to protection and how to avoid losing its benefits. It is futile to discuss the extent to which rights in intellectual property are to be protected if the processes of securing any benefits at all are so cumbersome that access to them is impractical. Dependence upon bilateral relations requires an intimate knowledge of the laws of every foreign country to know whether the publication of a book, the presentation of a play, or the exhibition of a motion picture in the United States will affect adversely the right to enjoy copyright in any or all of those countries. It is necessary to be familiar with all of the local requirements upon which the enjoyment of copyright is conditioned in those countries and to comply, if possible, with all of them. This is both a precarious and burdensome procedure. The rigidity and uncertainty of our own notice requirements, the possibility that a copyright may be nullified by failure to comply with some registration and deposit provisions of the Copyright Act, and above all the necessity that all books and periodicals first published abroad in the English language must be registered for ad interim copyright within six months and must be reprinted in the United States within five years or else lose the benefit of copyright, not only are difficulties which foreign authors now face in seeking copyright protection under our law, but are indicative of the kind of meticulous conditions which our own nationals may be required to cope with in foreign markets. Experience has shown that any attempt to secure protection solely on the basis of our bilateral relationships is a monumental, if not impossible, task. ${ }^{22}$

${ }^{10}$ Wheaton v. Peters, 8 Pet. 59 I (U. S. $x 834$ ); Schuiman, Author's Rights, 7 Copyrigur Pronlems ANALYZED I9, 25-27 (I952). One problem in international copyright is the definition of publication. See Berne Convention (Brussels revision) Art. 4(4); Universal Copyright Convention, Art. VI. 'The draftsmen of the Inter American Convention of 1946 could not agree on a definition for the purpose of that treaty. See Canyes, Colburn, and Pinzza, Copyright in the Americas, op. cit. supra note 7, at 22.

${ }^{20}$ I7 U. S. C. $\$ 9$ (Supp. I952).

${ }^{21}$ Copinger and SRONe JaMes, $\sigma p$. cit. supra note $x 7$, at 29 . On the sharp divergence between basing copyright on the nationality of the author and the criterion of place of publication, sec Report of Work of Third Committee of Experts, 3 UNESCO Copyright Bulletin Nos. 3-4, p. 24 (1950).

${ }^{22}$ Nicholson, A Manuaz of Copyright Practice ioo, 105 et seq. (1945); Canyes, Colionn, AND PIzZA, op. cit. supra note 7, at 174-175; DE WoLF, op. cit. supra note 14 at $182-187$. Copyright procedures, which in theory appear to be disarmingly simple, unfortunately turn out to be complex in actual 
The alternative to the method of bilateral arrangements is adherence to a multilateral treaty or convention by which some degree of uniformity of access to the benefits of domestic laws in a number of countries is established. This alternative was adopted by the United States in its relationships with the Latin-American Republics. By our ratification of the Buenos Aires Convention, our nationals, by printing a notice of reservation of copyright in their works, are relieved of the burdens of compliance with many local formalities in the treaty states. ${ }^{23}$ Despite its inadequacies, and a general belief that the Convention needs revision, it has been helpful in our relationships with our Latin-American neighbors. Argentina recently ratified the Buenos Aires Convention, but, unfortunately, neither Mexico nor Cuba is a party to it. ${ }^{24}$

We are not parties to any other multilateral treaty on copyright, but in the area of the Berne Union our authors and industries have been the fortunate beneficiaries of access to Berne Convention protection, even though the United States is not a party to the treaty. The works entitled to protection under the provisions of the Berne Convention are not only those first published in a Berne country, but also those published there simultaneously with publication in another country. ${ }^{25}$

practice. For example, copyright in a published work is secured in the United States by the imprinting of a statutory notice on each copy. Washingtonian Company v. Pearson, 306 U. S. 30 (1939). But, except in the most conventional cases, no one is quite sure of the adequacy of the notice. National Comics Publications v. Fawcett Publications, r9x F. 2d 594 (2d Cir. 195 I), illustrates the type of jigsaw puzzle with which the courts are presented, not to determine ownership or originality of the work or the question of its infringement, but to decide whether statutory formalities have been observed. Heim $\mathrm{v}$. Universal Pictures Co., I54 F. 2 d 480 (2d Cir. 1946), has created uncertainty about works first published abroad without a copyright notice, and the question whether they fall into the public domain in the United States. The failure to imprint the proper copyright notice, or to affix it in the proper place, results in a complete loss of copyright so it is never possible to generalize about compliance with formalities. Only intimate familiarity with the cases can explain the distinctions which courts have made betwcen those deviations which will not impair the copyright and those which will be fatal. See for example, Horace G. Ball, Law of Copyright and Literary Property, ch. VI, pp. I55-I74 (I944). Registration of the copyright and deposit of the work is optional except as a procedural prerequisite to the commencement of an action for infringement. However, the failure to deposit a work in response to an affirmative demand by the Copyright Office will nullify the copyright. $x_{7}$ U.S.C. $\$$ I 4 (Supp. 1952). The "manufacturing clause" presents another burden. All books and periodicals except those of foreign origin in a language other than English must be printed and bound in the United States to secure the benefit of copyright. I7 U.S.C. $\$ 17$ (Supp. 1952). Special provision is made for books of foreign origin in the English language which upon registration within six months become entitled to ad interim copyright for a period of five years. To have the benefit of the full term of copyright, the work must be reprinted in the United States within that five year period, and during the ad interim interval only $I, 500$ copies may be imported into the United States, 17 U.S.C. $\$ \$ 17,22,23$ (Supp. 1952).

${ }^{23}$ Buenos Aires Convention, Art. 3rd; Schulman, supra note 6, at $30 \mathrm{r}$; see Canyes, Colburn, and Piazzn, op. cit. stupra note 7, at 174; Sanders, The Protection of Intellectual Property of American Citizens in Latin America, 139 Publishers Weerly 2456 (June 2I, I94I); Nicholson, op. cit. supra note 22, at I13. Its lack of clarity had the unfortunate result of depriving Latin American composers of protection against phonograph recordings. Todamerica Musica Ltda. v. Radio Corporation of America, I 7 I F. 2d 369 (2d Cir. 1948); Portuondo v. Columbia Phonograph Co., 8I F. Supp. 355 (S. D. N. Y. 1937). Although we rely upon the Convention, its effect is limited and its efficacy uncertain, particularly if similarly rigid construction is adopted in other countries.

${ }^{34}$ Mexico ratified the Convention in February, 1953, but its instrument of ratification has not as yet been deposited; the parties to the Convention are Argentina, Brazil, Colombia, Costa Rica, Dominican Republic, Ecuador, Guatemala, Haiti, Honduras, Nicaragua, Panama, Paraguay, Peru, United States, and Uruguay.

${ }^{20}$ Berne Convention Arts. 4, 6. 
In many of the Berne countries, publication is construed to mean merely the offering of copies for sale to the public, no matter where the editorial or manufacturing work is done. ${ }^{26}$ Taking advantage of this combination of elements, our nationals have adopted the practice of sending copies of books or other published works to Berne Convention countries, such as England or Canada, and placing them on sale there simultaneously with the release of the works in the United States. In that fashion, the work acquires the technical status of English or Canadian origin within the meaning of the Berne Convention, and protection is claimed under the treaty.

Because protection under the Berne Convention is not conditioned upon formalities, ${ }^{27}$ the risks and burdens of following our own bilateral system have been avoided through the enjoyment of treaty rights by indirection. It is generally recognized that this method of circumventing the inadequacies of our direct copyright relations is both undignified and precarious. Not all countries accept the principle of publication which makes our access so easy, and the Berne Convention itself contains provisions whereby the extent of this access may be curtailed. ${ }^{28}$

Efforts to find a remedy for this troubled state of international copyright have continued for many years. The question of adherence by the United States to the Berne Convention has been the subject of a number of hearings before the Senate. ${ }^{20}$ The Berlin revision of 1908 was submitted by President Hoover in 193r, and the Rome revision by President Roosevelt in I934. Because of strenuous opposition, no action resulted.

The Rome Convention of the Berne Union in $\operatorname{rg} 88$ had in the meanwhile recommended that an attempt be made to create a world-wide convention. This recommendation was followed in September, $\mathrm{x} 928$, by a resolution of the Assembly of the League of Nations requesting its council to investigate the desirability of a general agreement for the protection of intellectual property. At the request of the League, the International Institute at Rome, for the Unification of Private Property, made an intensive comparative study of the Berne and Havana Conventions. Later, that Institute and the International Institute of Intellectual Cooperation in Paris, appointed a Committee of Experts to consider the problem of international copyright. This Committee met at Paris in April, I936, and considered a draft of a universal convention which had theretofore been prepared jointly by the Rome and Paris

\footnotetext{
${ }^{26}$ Copinger and Skone James, The Law of Copyright 26, 273-274 (8th ed. 1948); Harold G. Fox, The Canadian Law of Copyright 65-64, 548 (x944).

${ }^{22}$ Berne Convention Art. $4(2)$.

${ }^{28}$ Copinger and Skone James, op. cit. supra note 26, at 274-275; Saher, American-Netherlands Copyright Problems, I World Trade L. J. 37x (1946); Hirsch-Bali.in, Copyright Protection of Amenican Books in The Netherlands 7-9 (1950); Berne Convention Art. 6.

${ }^{20}$ Hearings before the Senate Committce on Foreign Relations on S. r928, 73d Cung., 2d Sess. (1934); Hearings before the Senate Foreign Relations Committee on Executive $E$ (International Copyright Convention), 77th Cong., Ist Sess. (I94I); Hearings before the House Committee on Patents on H. R. 6990, 7rst Cong., 2d Sess. (1930); ExEc. Rep. No. I, 75th Cong., 2d Sess. (1937); ExEc. Riep. No. 2, 76 th Cong., ist Sess. (1939).
} 
Institutes. ${ }^{30}$ Since the Belgian Government had theretofore issued an invitation to the member nations of the Berne Union for a conference to be held at Brussels in 1936, the Committee of Experts recommended the postponement of that meeting so that a special conference might be called to precede and be separate from the meeting of the Berne Union. The purpose of this special conference would have been to explore the possibilities of establishing a Universal Convention. The draft convention prepared by the Paris Institute was approved by the Experts Committee, and it was then circulated by the Belgian Government among the various nations of the world. The Experts Committee, later reconvening at Brussels in October, I938, proposed possible solutions which may be summarized as follows:

(a) The amendment of the Berne Convention so that American states might retain the right to require a single formality as a condition of copyright protection. This formality would be either a formal reservation of rights, i.e., something in the nature of a copyright notice, or a system of international registration entrusted to the Berne Bureau.

(b) The creation of a new Convention, to be substituted for the Berne and InterAmerican Conventions, which might effect a compromise between these respective systems.

(c) The creation of a new Convention which would not interfere with either the Berne Union or the Inter-American Convention. These would be left intact as between their signatory states, and the new Convention would govern their other international copyright relationships.

Although the intervention of the second World War terminated this project, various straws in the wind gave indications that the only possible solution would be the creation of a new convention. An attempt to revise the United States Copyright Act as a preliminary to ratification of the Berne Convention failed completely. ${ }^{31}$ The new Inter-American Convention, in preparation for a number of years and signed on June 22, I946 in Washington, D. C., met determined opposition. ${ }^{32}$ And out of these failures the lesson could be learned that a convention to be acceptable in the United States must take the following factors into account:

(a) Formalities could not be eliminated entirely.

(b) The moral right, which under the Berne Convention affords an inalienable privilege to an author of objecting to changes or alterations of his work prejudicial to his honor or reputation, could not be written into a convention no matter how much it was watered down.

(c) Retroactive recognition of copyright in works which had fallen into the public domain would not be tolerated, irrespective of the safeguards and limitations with which the provision might be surrounded.

(d) The development of the Berne Convention as an international statute requiring

${ }^{30}$ Report on Status of INTERnational Protection, Committee for the Strudy of Copyright (Columbia U. Press, 1938); Crewe, National Treatment as a Basis for a Universal Copyright Convention, 3 UNESCO Copyright Bulletin No. I, p. 3 et seq. (1950).

${ }^{31}$ A proposed revision of the Copyright Act was prepared by the Committee for the Study of Copyright and introduced by Senator EImer D. Thomas of Utah, as S. 3043 on Jan. 8, I940. It had been drafted after consultation with all groups interested in copyright but no unanimity could be gained for the support of the bill.

${ }^{32}$ See note 9 supra. 
substantive changes in domestic law on matters beyond the scope of international relationships was an insurmountable deterrent to its acceptance in the United States.

(e) Dissatisfaction existed with the Berne Convention method of providing for copyright protection in principle with a broad reservation for dilution by domestic legislation, since this created a great deal of uncertainty about the actual effect of these provisions.

(f) There was the necessity of providing a more adequate method of protecting the author's translation rights than the reservation permitted by the Berne Convention.

These areas of controversy not only made ratification of the Berne Convention impossible, but precluded any hope of amending that treaty sufficiently to achieve adherence from the United States.

In 1947, the newly organized United Nations Educational, Scientific and Cultural Organization (UNESCO) undertook to continue the study of international copyright. With the advice of a committee of experts, it embarked upon a program of making and publishing comparative studies of domestic laws, of circulating and seeking governmental reactions to recommendations concerning the content of an international convention, and of encouraging national and international discussions of the question. The reactions to the various recommendations which were circulated reinforced the conclusion that the only cure for the ills of international copyright was the creation of a new convention, not revision or modification of the existing treaties. It became apparent as well that neither the Berne Convention nor the Pan-American Convention could be entirely superseded, since many of their respective adherents would not consent to abandon as between themselves the benefits they derived from the existing relationships. ${ }^{33}$

With these conclusions, the course of action became clearer and the way was open for the development of a new treaty. It was evident that the new convention would have to effect accommodations between conflicting traditions and philosophies instead of choosing one of them to the exclusion of the other, should be limited to the elements essential for international protection, and must refrain from interference with domestic public policies wherever possible. ${ }^{34}$

After five years of intensive work, the Universal Copyright Convention was

${ }^{33}$ The work of UNESCO on Copyright from its inception in 1947 through the Geneva Conference in 1952 can be read in the UNESCO Copyright Bulletin, published from $194^{8}$ through Volume 6, No. I, published in 1953 . Articles by some of the members of the committees served to crystallize the problems; sce Mendilaharzu, The Bases of a Universal Convention on Copyright, 3 UNESCO Copyright Bulletin No. I, pp. 35, 38, 39 (1950); El-Tanamli, Right of Translation and the Public Interest, id. at 88 et seq.; del Castillo, Copyright and the Use of Foreign Works, id. at 13 et seq.; Escarra, Comment on International Copyright Protection, 2 UNESCO Copyright Bulletin No. 4, p. 2 et seq. (1949); de Sanctis, A Universal Convention and a Minimum of Protection, 3 UNESCO Copyright Bulletin No. $x$, p. 7I (1950); Schulman, A Pattern for a Universal Copyright Convention, id. at 81, 83.

${ }_{34}$ The UNESCO Copyright Bulletin published, in addition to the comparative studies made by that organization, articles written by participants in the committee hearings, detailed summaries of the discussions at committee meetings, and the proceedings at the Geneva Conference. A survey of the work done without too much detail may be had from the various reports of the Rapporteurs-General, as follows: Dr. Luther H. Evans (United States), 2 UNESCO Copyright Bulletin Nos. 2-3, pp. 154 et seq. (1949); W. P. J. O'Meara (Canada), 3 id. Nos. 3-4, p. 15 et seq. (1950); G. H. C. Bodenhausen (The Netherlands), 4 id. No. 3, p. 17 et seq. (1952); Sir John Blake (United Kingdom), 5 id. Nos. 3-4, p. 42 et seq. (1952). 
evolved. The program in the United States had the cooperation of a panel of copyright specialists representative of all groups interested in the creation and utilization of literary property. ${ }^{35}$ The panel acted under the chairmanship of Dr. Luther $\mathrm{H}$. Evans, then Librarian of Congress, with the assistance of the Register of Copyrights, Arthur Fisher, and Roger C. Dixon of the State Department.

The new Convention has taken into account and has attempted to overcome all of the hurdles which have heretofore prevented agreement on international copyright. It recognizes the existence of different traditions and different copyright doctrines, and that because of cultural and economic considerations national public policies may vary and continue to vary from country to country. The underlying philosophy of the new Convention is in a great measure similar to that upon which our federal system of government is based. There are areas of local concern where the rights of individual states are predominant, but in other matters adjustments must be made to support the flow of commerce across state lines.

In conformity with its essential pattern, the treaty does not purport to be an international statute, nor is it self-executing. Domestic legislation will be required to implement its provisions. Not being an international statute, the treaty, unlike the Berne Convention, ${ }^{36}$ does not list in detail the categories of works which must be protected, but allows each state to define what constitutes a literary, scientific or artistic work, within the meaning of copyright and within the general concept of writings, musical, dramatic and cinematographic works, and paintings, engravings, and sculpture. Each country may, therefore, determine for itself whether oral or architectural works, or industrial designs or works of applied art, shall come within the scope of its copyright laws. The quality of protection is also left to the public policy of each state so it may determine for itself whether all public performances or only those for profit shall come within the exclusive right of copyright owners, whether compulsory licenses are to be imposed, or certain uses exempted from the author's exclusive right, or whether the author's inalienable moral rights should or should not be enforced under its domestic law. All that the Convention requires is that there be an actual copyright system and that when a state establishes the policy for its own nationals, the foreign author shall receive equality of treatment.

In the matter of access of foreign works to the benefits of the domestic law, the Universal Convention does not attempt to settle the philosophical differences between our tradition that copyright in published works must be claimed in order to be enjoyed, and the Berne philosophy which has abolished formalities. It establishes a pragmatic and easily applied method of satisfying all formal requirements by the adoption of a symbol in the nature of an international passport. Under the terms of the convention the use of a symbol- - -accompanied by the name of the copyright proprietor and the year of publication, affixed in a fashion which will give reasonable notice that copyright is reserved, will for international purposes

${ }^{3 t}$ See Exec. M., 83rd Cong., Ist Sess. 3-4 (1953). Art. I.

${ }^{30}$ Compare Berne Convention (Brussels Revision) Art. 2, with Universal Copyright Convention 
satisfy all of the variety of present-day formal conditions for securing copyrightwhether they be notice, registration or deposit, or domestic manufacturing or publishing requirements. ${ }^{37}$ Under this method, a book published in the United States, a song published in France, or a periodical published in England, if it bears this symbol, will have access to the benefits of copyright throughout the convention area. Each state may, however, require of its own nationals whatever formalities it desires. A belief has been expressed in some quarters that the requirement of even a simple notice should be eliminated. However, as a result of the uniformity and simplicity of the convention requirement, much of the hazard of loss of copyright is minimized. Each country may without pressure of a convention reconsider for itself the necessity of continuing its system of formalities.

Earlier in this article references were made to the contrasts in treatment of published and unpublished works, and the differences between the criterion of the nationality of the author and that of the situs of publication as the basis for according copyright protection to works of foreign origin. The Universal Convention again does not attempt to decide between these conflicting doctrines. It establishes as the broadest basis for the extension of copyright benefits that both published and unpublished works originating under the Convention be protected, and that protection be accorded not only when the author is a national of a contracting state, but also where the work is first published in one of these states. In this way, the rights of both author and entrepreneur are given recognition.

The new treaty similarly recognizes the variation in doctrine between the United States and the rest of the world on the duration of copyright. ${ }^{38}$ In this country, copyright in published works and in those unpublished works which are registered for statutory copyright, continues for a term of twenty-eight years from publication or registration as the case may be, with a renewal period of equal length. ${ }^{30}$ In other countries, the term endures during the lifetime of the author and a period of years thereafter. The last revision of the Berne Convention at Brussels in I 948 prescribes a minimum of fifty years post mortem. ${ }^{40}$ There is much to be said for both methods of computation, but the Universal Convention instead of attempting to choose between them, permits both systems to continue side by side. There is, however, the limitation that any contracting state may, if it so chooses, limit the copyright term in its own territory to that of the country of origin of the work. This has been a common device in international copyright, although for the most part convention countries have not insisted upon its application.

Translation rights have presented many difficulties. There was a time when the translation of a book was not considered a copying and was not therefore an

${ }^{37}$ U. C. C. Art. III; see Schulman, Another View of Article III of the Universal Copyright Convention, [1953] WIs. L. Rev. 299-30I. However, compare Warner, The UNESCO Universal Copyright Convention, [1952] Wis. L. REv. 493.

${ }^{38}$ Art. IV.

${ }^{30} 17$ U. S. C. $\$ 24$ (Supp. 1952).

10 Berne Convention (Brussels Revision) Art. 7. 
infringement of copyright. ${ }^{41}$ However, in the United States and in most culturally developed countries, copyright includes the exclusive right of translation. ${ }^{42}$ There are, on the other hand, some portions of the world which have not as yet reached this stage of development and where the author is given no control or only a limited control over the right to translate. The Berne Convention has wrestled with the translation problem for a long time and has permitted an adhering country to limit translation rights into local languages to ten years from the time of publication of the original work. This solution has not been entirely satisfactory or realistic. ${ }^{43}$ It is small comfort to an author who writes in English to be told that his work will be protected against actual "copying" in a country where no English books are sold, but not against the translations which would find a market. Yet there is a strong belief in some countries that they must be entitled to limit translation rights. The solution adopted by the Universal Copyright Convention is frankly a sompromise.

The treaty provides ${ }^{44}$ that copyright shall include the exclusive right of the author over translations. However, an adhering country may curtail this right by domestic legislation, but only within narrow limits. A country seeking to avail itself of this opportunity may by its domestic law provide that if within seven years from the date of the original publication of the work it has not been translated into the country's natural language (or one of them) a non-exclusive statutory translation license may be granted by a competent authority of that country. This possibility of diluting the translation right is hedged about with a number of safeguards for the protection of the author, among them being provisions for notice to the owner of the translation right, for assurance of payment of royalties, and for assurance of the accuracy of the translation.

The compromise has the virtue of establishing the principle that protection against unauthorized translation is necessary to establish actual instead of theoretical national treatment. The fixed period of absolute protection provides an opportunity for the proprietor of a work to arrange for translation. The requirement that some attempt be made to reach an agreement before a statutory license can be claimed should encourage voluntary arrangements. The requirements that royalties be paid throughout the copyright period under any statutory license and that the accuracy of the translation must be safeguarded not only are just but should in the long run eliminate hostility between the proprietors of original works and translators. Only time will tell whether this pragmatic solution will or will not work, and whether it will eventually lead to the full protection of the author's right of translation.

\footnotetext{
${ }^{21}$ See Stowe v. Thomas, 23 Fed. Cas. 20I, No. 13,5I4 (C. C. E. D. Pa. I853); Eaton S. Drone, A Treatise on the Law of Property in Intellectual Productions in Great Britain and the UNITED STATES 52, 445-456 (I879).

${ }^{42}$ I7 U. S. C. $\$ \$ 1,7$ (Supp. 1952); 2 UNESCO Copyright Bulletin Nos. 2-3, p. 24 (1949).

${ }^{13}$ Art. 8 of the Brussels Revision of Berne must be read with Arts. 25(3) and 27(2); see also note 33 supra.

"U. C. C. Art. V.
} 
Of equal importance with the accommodations made in the area of affirmative agreement are the pitfalls which have been avoided. There is no requirement for the recognition of a moral right, and retroactive application of the Convention to works in the public domain is specifically precluded. ${ }^{45}$ Ratification of the Convention may not be subjected to reservations as to any of its obligations.

The Berne Convention continues intact as between its member countries, and safeguards are interposed against the impairment of the Berne Union by reason of the new treaty. ${ }^{46}$ Conventions in force between American Republics, and other multilateral and bilateral arrangements, are not abrogated, but will continue except to the extent that there is a difference in the respective provisions. ${ }^{47}$ In that case, the later treaty or arrangement in point of time will prevail between the parties to it.

As a realistic and workable agreement, the Universal Copyright Convention should be acceptable to the entire free world, despite its lack of those refinements which have caused the Berne Convention to be the means of elevating copyright standards in many countries. The step toward world-wide agreement on international copyright relationships may be modest, but it is of the utmost significance. Never before has a convention been prepared by the joint efforts of so many countries from so many divergent parts of the globe.

In the United States, the new Convention should be particularly welcome since it will not require any change in our substantive copyright law. The changes required would, in respect to foreign works, extend the use of the symbol $\oplus$ to all works instead of the limited class on which it may now be used, would make the location of imprint of the notice less rigid, would eliminate requirements for deposit of works to the extent that they are a condition of copyright and not merely a procedural step in litigation, ${ }^{4 \mathbf{7 2}}$ would extend copyright to works first published in a proclaimed state in addition to works of which nationals of that state are the authors, and would eliminate the domestic manufacturing requirements for books and periodicals of foreign origin in the English language.

The manufacturing requirements of our Copyright Act were part of the compromise reached in I89r and again in r909 when international copyright was conceived in terms of the importation of British books. ${ }^{48}$ They do not apply to books of foreign origin in languages other than English, or to musical compositions or plays even when printed in book form. ${ }^{49}$ The manufacturing clause was a protective device applicable to an era when the United States depended upon England for its

${ }^{45} I d$. Art. XII; compare with Berne Convention (Brussels Revision) Art. I8.

${ }^{4} I d$. Art. XVII and Appendix Declaration.

${ }^{47} 7 d$. Arts. XVIII and XIX.

${ }^{47}$ See note 22 supra.

${ }^{48}$ See Richard R. Bowker, Copyright, Its History and Its Law 365 et seq. (1912): George H. Putnal, The Question of Copyright iv, 273 (2d ed. I896).

${ }^{10}$ I7 U. S. C. $\$ 16$ (Supp. I952); Hervieu v. J. S. Ogilvie Pub. Co., 169 Fed. 978 (C. C. S. D. N. Y. 1909); Littleton v. Oliver Ditson Co., 62 Fed. 597 (C. C. D. Mass, 1894); DE Wolf, AN Outhine or Copyright LAw 52 (1925); Howell, THE Copyright LAw 93 (3d ed. 2952). Sec Hearings before the Committee on the Judiciary on H. R. 4059, 82nd Cong., 2d Sess. (1952) (a bill to modify the manufacturing provisions). 
literature, and before it became a producer and exporter of books and periodicals, of music, plays, and motion pictures. However necessary this device may have seemed some forty years ago, it no longer has any economic function or any place in the international copyright structure today.

Whether the Universal Copyright Convention will ever become effective rests with the United States. If the treaty is ratified by us, it will undoubtedly receive wide adherence throughout the free world. Failure to achieve ratification in this country will spell its doom and leave as the only remaining alternative a continuance of our outmoded and inadequate system of bilateral arrangements. We can hardly hope again to obtain agreement upon a treaty more tailored to our own pattern of copyright law. 